\title{
A Stroll Through English Libraries
}

\author{
Dr. Lederer is a fellow of the Library of \\ Congress.
}

$\mathrm{W}$

HEN VISITING English libraries, one looks back to six centuries of devoted service to the reader. Within convenient range of the traveler are London and $\mathrm{Ox}$ ford. The libraries of these two cities offer a good choice for a general view.

Let us start with Oxford, the ancient seat of learning for almost seven centuries, whose coat of arms humbly points to the eternal source of all truth and wisdom: Dominus illuminatio mea. In the venerable Merton College Library - the building was erected in the years $1373-78$ - the lanceshaped, narrow windows throw a dim light on rows of leather-bound volumes, the gilt titles and edges of which have long ago faded. The structure and arrangement are, on a smaller scale, similar to those of the Bodleian Library. There is a central aisle with bays on both sides and the books on shelves above the desks - simple boardswithin easy reach of the reader. Valuable books were chained to the shelves-as still may be seen-to be on the safe side in those insecure times. In those days the work of a scholar must have been somewhat less cumbersome than now, to judge from the signs on top of the frontsides of the bays; only a few bays were dedicated to the old "schools" of theology, jurisprudence, medicine and philosophy. A few shelves sufficed for what was probably the whole knowledge in each field. In the corner where two wings form a right angle is a bust of $\mathrm{Sir}$ Thomas Bodley whose name is forever connected with the Bibliotheca Bodleiana. The old Merton College Library is hardly used now, a modern library having been established right below the old one. The Bodleian Library, however, is still, as it has been for ages, a working library, not only one of the most revered, but also one of the largest and most important institutions of its kind.

The old Bodleian is too well known to require a minute description. Generation after generation has climbed the shallow steps of the quaint wooden staircase. One would not suspect when passing the modest entrance in a corner of the Old Schools Quadrangle that he was entering one of the noblest repositories of man's wisdom and learning. Founded in the fifteenth century it was despoiled roo years later, and then restored by Sir Thomas Bodley at the end of the sixteenth century. The I-square shaped hall with its beautiful old roofing, adorned with college arms, has been the workshop of countless scholars. There are untold treasures among the 42,000 bound volumes of manuscripts, oriental and western, some dating from the fifth century. The "Theorem of Pythagoras" can be seen in a manuscript of Euclid's Elements, almost I 100 years old. King Alfred's AngloSaxon translation of St. Gregory's Liber pastoralis, the Cura pastoralis (890-897) next catches our eye.

Thousands of manuscripts and incunabula, and two million books fill the stacks of the New Bodleian Library. This modern structure-too modern, perhaps, for many old Oxonians in these noble surroundings of the Clarendon building, the Old Schools Quadrangle, Exeter and Trinity Colleges-was finished in 1940 , at the time of the "phony" war. During the war the premises were used by the government. 
The library was formally opened by the King and Queen in 1947, exactly 500 years after the opening of the oldest part of the Bodleian, which once contained the manuscripts of Humphrey, Duke of Gloucester. The New Bodleian meets all the standards of a modern library. The light and large reading room, which is used mainly by students in the social, economic and historical fields, contains an excellent reference library for the convenience of the readers. All the other books, including the valuable old manuscripts, are brought over to the old Bodleian reading room by means of an electric conveyor leading through an underground tunnel which connects the two buildings, the calls being transmitted by means of pneumatic tubes. S. Gillam, assistant secretary, serves as an expert guide through all the intricacies and technicalities of a modern library. The steel shelves are similar to those of the Library of Congress, but the books are shelved by size as indicated in the call number, a-d. The subjects are indicated by a number system which is used by this library exclusively, and the individual works are arranged alphabetically within the size groups. A special peculiarity which dates far back is that newspapers are bound by date, with titles in alphabetical order. This makes it possible to view the news of the day from various political angles. To trace a particular fact, however, it is necessary to know the exact date.

Many volumes, especially manuscripts and early prints, are turned with their backs to the wall, the call number written in ink on the edges. They were originally chained and one can still see the spot where the chains were fastened to the covers. The divisions are the same as in any other large library, but are modestly termed "rooms," e.g. a cataloging room, a map room, etc. Although the simple cataloging system used does not require a large staff of specialists and is actually done in a single room, the process takes much longer because of the traditional use of ledgers rather than cards. The slips for the entries, formerly written, are now printed on sheets which have to be cut; then the single slips are pasted on the left-hand pages of the ledger, and additions on the right-hand pages. To catalog new accessions, slips have to be removed and moved on until the page, or the entire volume, is ready for a new, up-to-date arrangement-which, however, does not stay up-todate very long. This system is certainly less flexible than the use of cards, and it takes longer for new accessions to be entered. On the other hand, it is more convenient to look over an author's complete work, or a subject, in a bound volume than to go through long files of cards. Because of the simple procedures the library requires a relatively small personnel; the whole staff includes only 100-120 persons. It is true, however, that it sometimes takes an hour before a book is received by the reader and the catalog may not yet record a book which has been received months before. On the whole, however, it does function if one may conclude from the scholarly work which has been accomplished in the Bodleian Library. And here they are still sitting either in their traditional, time-honored cap and gown or in the plain clothes of our more prosaic age: the young student trying out his first groping steps in the universe of letters; the famous scholar, sure of his ways through the labyrinth of knowledge neatly bound up between covers, tracing the steep paths which lead to unknown lands no man's eye has ever beheld.

The magnificent library of the British Museum, one of the largest of the world, with approximately four million volumes is a comparatively modern institute compared with the old Bodleian. The magnificent dome of the reading room, which was only slightly damaged during the war, houses an excellent reference library accessible to the 
reader. Arthur Ellis, the keeper, one of the leading officers of the library and a noble type of a quiet and friendly English scholarlibrarian, F. D. Cooper, assistant keeper of printed books, first class, and for many years in charge of the Documents and State Paper Room, and Mr. King, in charge of the Music Room, dedicated a good deal of their precious time to inform this visitor about the library in general and to show him around in the various divisions, here, too, called rooms. As in the Bodleian we are again surprised at the simplicity of the procedure. The cataloging system is similar to that of the Bodleian, although the numbers used for the subjects are different; and here, too, the books are cataloged and shelved by size. Cataloging is done in two rooms by about two dozen employees. A staff of about Io persons in two rooms handle the copyright. Here, as in the Bodleian, ledgers are used, not cards. The stacks are, naturally enough, somewhat old fashioned and filled to the high ceilings with shelves so that ladders must be used. Thousands of volumes of medieval manuscripts, incunabula and historical documents (e.g. a copy of the Magna Charta) make the British Museum Library a worthy rival of the Old Bodleian. Numerous collections are kept together, many of them in special period-furnished rooms. The library suffered heavily during the war; about 200,000 volumes have been lost entirely, many more thousands damaged. In many parts of the building, especially the "King's Library" the destruction provides a grim reminder of the war devastation.

Neither the Bodleian, nor even the British Museum Library are public libraries in the sense that the prospective reader may simply walk in and order a book as he will do in the New York Public Li- brary or in the Library of Congress. There he has to get a personal permit either for the day or a longer period, stating precisely the object of his studies.

A neighbor of the British Museum Library is the University of London Senate House and Library. This is a modern skyscraper, housing 500,000 books and serving a student body of 50,000 residents and about 20,000 nonresidents, besides the faculties of 40 affiliated schools, as the librarian, J. H. P. Pafford, explains. It has a beautiful reading room with a reference library and all the facilities for quick and expert service. The library specializes in political and social sciences. The single institutes (e.g. for Slavonic studies and history) in the same building have their own special libraries.

This little stroll through libraries in England concludes with a glance at a small but important collection: the American Library on Grosvenor Square, next door to and connected with the American Embassy, numbering only about 10,000 volumes, has developed into an indispensable reference library on American questions - as its director, Sargent Child, formerly of the Library of Congress, points out. This is a difficult assignment for such a small collection but one that is solved successfully. Not all the answers can be found in books, however. Hence a good deal of the work consists in answering telephone calls from embassies, government offices, representatives of industry and trade, etc. This service is provided by a small but well-trained and informed staff. This institution, which has existed only a few years, is a worthy symbol of American culture and efficiency in the heart of England, and although small, it constitutes an important link between the English-speaking nations. 